\title{
Tourism Development in Malaysia from the Perspective of Development Plans
}

\author{
Md. Anowar Hossain Bhuiyan ${ }^{1,2}$, Chamhuri $\operatorname{Siwar}^{1} \&$ Shaharuddin Mohamad Ismail $^{1}$ \\ ${ }^{1}$ Institute for Environment and Development (LESTARI), Universiti Kebangsaan Malaysia, Bangi, Malaysia \\ ${ }^{2}$ Lecturer (Management), National University, Gazipur-1704, Bangladesh \\ Correspondence: Md. Anowar Hossain Bhuiyan, Institute for Environment and Development (LESTARI), \\ Universiti Kebangsaan Malaysia, 43600 UKM, Bangi, Selangor Darul Ehsan, Malaysia. E-mail: \\ anowaranu@yahoo.com
}

Received: February 22, 2013 Accepted: April 25, 2013 Online Published: June 12, 2013

doi:10.5539/ass.v9n9p11

URL: http://dx.doi.org/10.5539/ass.v9n9p11

\begin{abstract}
Tourism is a potential matter in social, environmental and economic levels of government agendas. Tourism is a mentionable earning industry of Malaysia. About 24.7 million tourist arrivals in Malaysia in 2011 and receipts RM 58.3 billion from this sector. Malaysian government has played a significant role in instituting legal and institutional framework for ensuring sustainable tourism. The present study discusses the tourism enhancement initiatives in development plans of Malaysia. The paper discusses Ninth Malaysia Plan and Tenth Malaysia Plan, Economic Transformation Program (ETP), National Tourism Policy (NTP), National Physical Plan (NPP), and Local Agenda 21 (LA 21) to discover tourism development perspective in Malaysia. The study reveals that foreign tourists arrival and tourist expenditure on the basis of per capita and per diem is increasing year by year. Tourism development is one of the key element for each development plans in Malaysia. Government has been giving special emphasize on the tourism sector during the each plan period. The government adopts and formulates various laws and regulations to ensure sustainable tourism development as well as implement necessary policies. Finally, Malaysia has targeted to capture a place within the top 10 countries in the world in terms of international tourist arrivals through various development plans.
\end{abstract}

Keywords: tourism, Malaysia, development plans

\section{Introduction}

Tourism is the leading and the single largest industry in the world of today. This sector has been recognized as one of the main important service industries in the world (Schumacher, 2007). Tourism is a potential matter in social, environmental and economic levels of many government agendas. Government sees tourism as a tool of development giving priority to protect the environments and traditions with minimum negative impacts (Liu \& Wall, 2006). Tourism is commonly used to widen economic enhancement of a country. The Third World countries encourage tourism development for their economic advancement (Hall, 1995). The poor countries develop their towns and regions by the tourism. Governments view tourism as a tool for infrastructure development, job opportunities, earning foreign exchange, balance of payments, regional development and generating benefits for local communities (Glasson et al., 1995). Tourism development can increase individual's income and revenues for host countries (Ahn et al., 2002).

The three most important economic features of tourism in developing countries are income generation, employment opportunity and foreign exchange earnings. Tourism plays vital role for economic development in this regard. This industry has different contribution on economy on the basis of each countries perspective. Tourism is the major foreign exchange earning source for many third world countries. In this regard, less developed countries (LDCs) consider tourism as an important tool for their economic development (Taleghani, 2010). Government of each country has given support in tourism sector for its enhancing and well-recognized economic benefits. Tourism can contribute in both macro and micro level economy development of a country. At macro level, tourism is a catalyst for foreign exchange earnings, revenue generation, balance of payment and contributing in gross domestic production (GDP). Community involvement, peoples' well-beings, job creation, income distribution, sustainable regional developments are micro level contributions of tourism. 
Tourism is a mentionable earning industry of Malaysia. This sector is selected as second engine for the growth of nation for developing global competitiveness. This industry effects positively on the Malaysian economy for increasing foreign exchange earnings, and employment opportunities (Bhuiyan et al., 2011). Malaysia has secured third position in tourist arrivals among the Commonwealth countries after Britain and Canada. According to the statistics of 2005 , tourism is contributing over $40 \%$ in the balance of payment of Malaysia and becomes the key foreign exchange earner of the country (Malaysia, 2006). In 2006, tourism contributed second largest foreign exchange earning sector after manufacturing. Tourism earned US\$18.1 billion in export revenue which is representing $10 \%$ of the total exports of Malaysia in 2006 (WTTC, 2006). The Malaysian government has given emphasize on the development of tourism industry in the middle of 1980s due to world economic recession and decrease in petroleum assets. The government had established Ministry of Culture, Arts and Tourism in this connection. In 2004, this ministry was named as 'Ministry of Tourism' (Fateh et al., 2009). The government has allocated sufficient fund for providing basic infrastructure in tourism industry. Malaysia has captured $2 \%$ of global market share of inbound tourism receipt in 2008. This industry employs 1.7 million workers or approximately $16 \%$ of total employment in 2008 (Malaysia, 2011b). Malaysian government has played a significant role in instituting legal and institutional framework for ensuring sustainable tourism. The present study discusses the tourism enhancement initiatives in development plans of Malaysia.

\section{Methodology}

The Government of Malaysia (GOM) has adopted development plans for the different duration to enhance the sustainable development in the country. Tourism development is one of the key element for each development plans. GOM has been giving special emphasize on the tourism sector during the each plan period. Here we discuss Ninth Malaysia Plan and Tenth Malaysia Plan for analyzing the tourism development. Moreover, Malaysia has also formulated the Economic Transformation Program (ETP) in 2010 to further enhance economic development in the country and tourism is one of the key sectors in ETP. Moreover, the paper also discusses National Tourism Policy (NTP), National Physical Plan (NPP), and Local Agenda 21 (LA 21) to discover tourism development perspective.

Ninth Malaysia Plan: The Ninth Malaysia Plan was adopted for 2006-2010 period. In this plan period, dynamic efforts have been taken in the tourism industry to increase its contribution to the economy. The major focus was to enhance Malaysia as a famous tourism destination in the world while promoting domestic tourism. The plan have been undertaken to coordinate in tourism resources and develop tourism infrastructure. The efforts have given emphasize to increase facilities and innovation for tourism products and services. High concern was placed and continued for achieving more sustainable tourism development.

Tenth Malaysia Plan: The Tenth Malaysia Plan also addresses tourism development during the period for 2011-2015. The plan gives emphasize to develop exciting and iconic tourism initiatives, to proper management of existing tourism destinations and to focus on tourism promotional activities. Within this plan period, Malaysia has targeted to reach in top 10 countries of the world in terms of global tourism receipts. The plan prioritized on promotional strategies for tourism development in the country.

Economic Transformation Program: The Economic Transformation Program (ETP) is a comprehensive effort that will transform Malaysia into a high-income nation by 2020. The government has formulated this program for significant change of Malaysia's economy like as developed country. ETP has selected 131 entry point projects (ETP), 60 business opportunities which ensure 92 percent private sector investment. This program will impact in gross national income (GNI) per capita from RM 23, 700 in 2009 to RM 48,000 and create 3 million new jobs by 2020. The 12 National Key Economic Areas (NKEA) is at the core of the ETP. The 12 NKEAs selected are: Oil, Gas and Energy; Palm Oil; Financial Services; Tourism; Business Services; Electronics and Electrical; Wholesale and Retail; Education; Healthcare; Communications Content and Infrastructure; Agriculture; and Greater Kuala Lumpur/Klang Valley.

\section{Discussions}

The growth of foreign tourist arrivals to Malaysia has been impressive with the total increasing from 7.13 million in 1996 to 17.4 million in 2006. The average annual growth rate was $9.41 \%$ in this period. On the other hand, receipts also have risen significantly from RM 10.35 billion in 1996 to RM 36.3 billion in 2006. Moreover, tourist arrivals reached 24.7 million and tourists receipts were 58.3 billion in 2011 (Table 1). The foreign hotel guests to Malaysia have been increasing from 12.31 million in 2000 to 22.45 million in 2006, an average annual growth rate of $10.5 \%$. Again, the domestic hotel guests also have risen 26.61 million in 2000 to 52 million in 2006. The average annual growth rate of domestic hotel guests was $15.2 \%$ in this period (Figure 1). 
Table 1. Foreign tourist arrivals and tourists' receipts to Malaysia, 2001-2011

\begin{tabular}{lcc}
\hline Year & Tourist Arrivals (Million) & Tourists Receipts (RM Billion)) \\
\hline 2001 & 12.7 & 24.2 \\
2002 & 13.2 & 25.8 \\
2003 & 10.5 & 21.3 \\
2004 & 15.7 & 29.7 \\
2005 & 16.4 & 32.0 \\
2006 & 17.4 & 36.3 \\
2007 & 20.9 & 46.1 \\
2008 & 22.0 & 49.6 \\
2009 & 23.6 & 53.4 \\
2010 & 24.6 & 56.5 \\
2011 & 24.7 & 58.3 \\
\hline
\end{tabular}

Source: Modified from Malaysia 2012

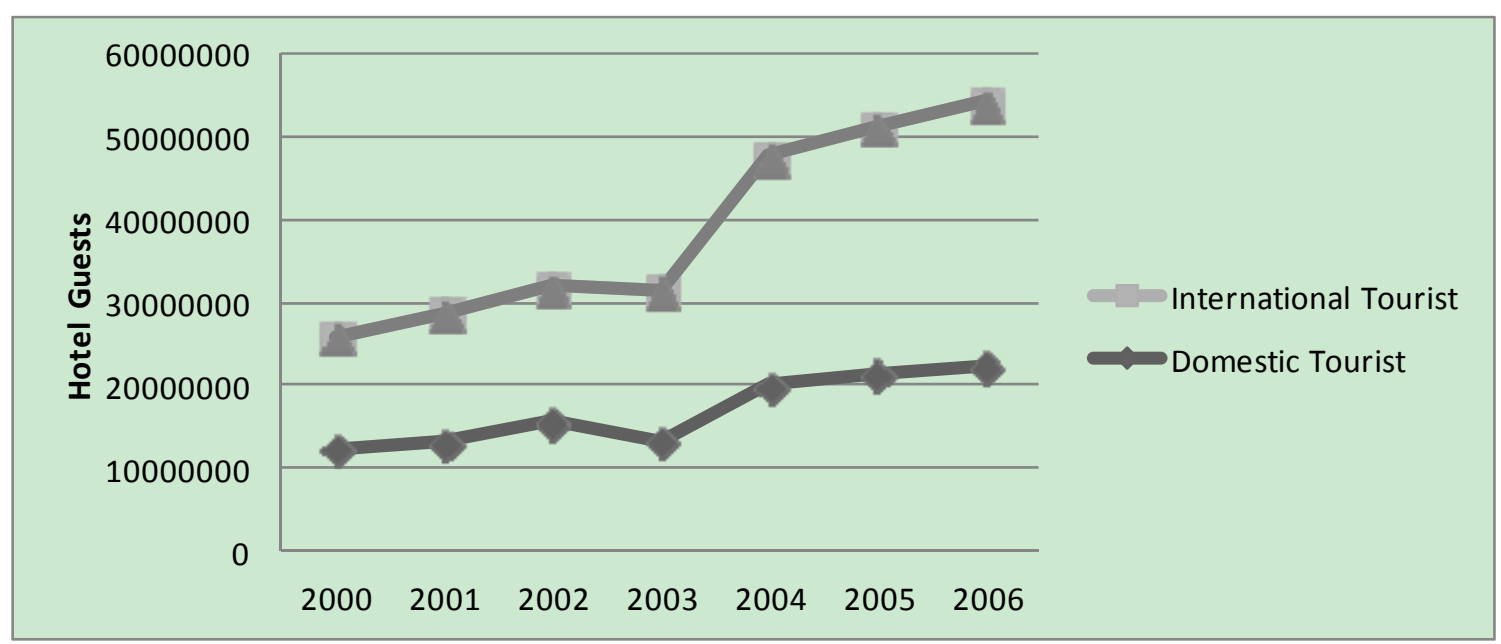

Figure 1. Foreign and domestic hotel guests for Malaysia, 2000-2006

Source: Modified from Malaysia 2007

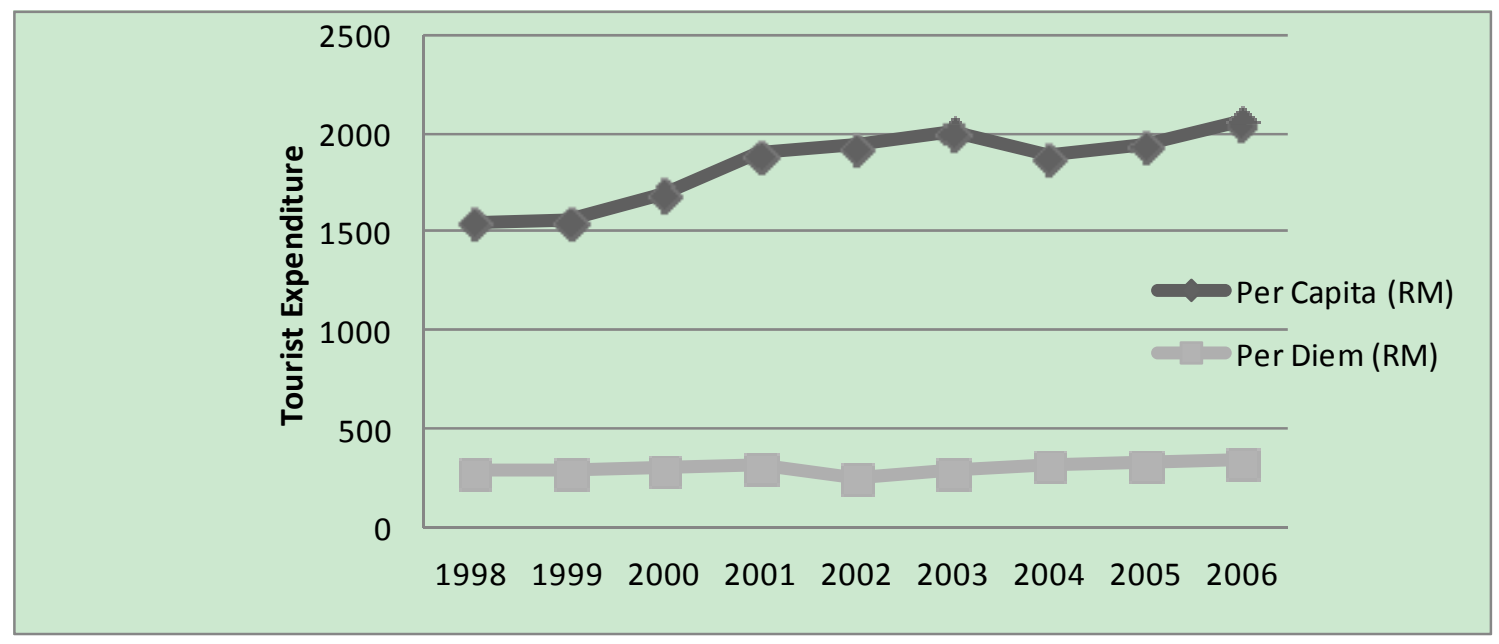

Figure 2. Tourist expenditure for Malaysia, 1998-2006

Source: Modified from Malaysia 2007 
Tourist expenditure for Malaysia on the basis of per capita and per diem are increasing year by year. In the year 1998 per capita expenditure amounted to RM 1,545.80 while per diem expenditure was RM 280.30. On the other hand, in the year 2006 per capita and per diem expenditure were RM 2,067.10 and RM332.70 respectively. Over the period 2005 to 2006 average per diem expenditure has increased by $4.3 \%$ (Figure 2).

\subsection{Ninth Malaysia Plan}

In this plan period, greater emphasis has been given to ecotourism through the protection of natural resources such as recreational forests, parks, beaches, islands and lakes (Malaysia 2006a). The key initiatives for tourism development in this period were:

1) To attract the private sector investment for the growth of tourism industry;

2) To develop the quality of tourism services including improve the direction and coordination of the tourism activities;

3) To improve the diversification of tourism products and activities;

4) To give emphasize on ecotourism, agro tourism, culture and heritage tourism, home stay program and thematic events;

5) The government co-operated with the private sector for the marketing promotion of tourism;

6) An integrated approach has taken for ensuring sustainable development of tourism industry in planning and implementation;

7) To encourage the private sector to improve recreational facilities for increasing domestic tourism;

8) To emphasize on human development of tourism industry to meet the demand for efficient personnel in this sector;

9) To continuous research initiatives for tourism development by various programs and projects.

This plan has been undertaken an integrated approach between all related agencies and parties for sustainable tourism development in the country. This plan also gave special attention for human resource development and research initiatives for tourism sector and expand domestic tourism development. The main shortcoming of this plan was lack of sufficient guidelines for foreign investment in tourism development.

\subsection{Tenth Malaysia Plan}

The major initiatives for tourism development in Tenth Malaysia plan (Malaysia, 2011b) period include:

1) Creation of tourism clusters by improving existing and new iconic tourism products;

2) Developing private sector and public-private partnership in tourism sector;

3) Improving maintenances of tourist sites through multiple approaches;

4) Increasing promotional and advertising activities by Tourism Malaysia offices in overseas;

5) Promoting differentiated initiatives to provide exclusive and unique tourism patterns.

The plan gives more focus on tourism promotion and expands global tourism market. But the plan has no special emphasize for research and educational initiatives in tourism and human resource development for tourism sector.

\subsection{Tourism in Economic Transformation Program (ETP)}

Tourism is identifying as potential NKEA for 2020 vision in ETP. Malaysia has fixed target for tourism development during this transformation program period. The country will receive 36 million tourist arrivals and RM 168 billion tourist receipts by the end of 2020. NKEA have identified 12 initiatives for tourism development and achieving target for 2020. These 12 initiatives are defined as entry point projects (EPPs) under five themes to enhance the tourism sector. The EPPs will stimulate tourism growth from RM36.9 billion in GNI to RM103.6 billion in GNI by 2020 (Malaysia, 2010). The five themes and 12 EPPs are as follows:

\subsubsection{Theme 1: Affordable Luxury}

EPP 1: Positioning Malaysia as a duty-free shopping destination for tourist goods: The foreign goods price are higher in Malaysia rather than other neighboring countries due to impose high taxes. Malaysian government has developed the country as duty-free shopping destination to attract the foreign tourists. The Ministry of Tourism will implement this EPP in collaboration with the Ministry of International Trade and Industry. This project will increase shopping activities by foreign tourists from 28 percents in 2009 to 35 percents by 2020 . Total jobs will 
be created about 64,000 in this period.

EPP 2: Designating Kuala Lumpur City Centre-Bukit Bintang area as a vibrant shopping precinct: This project will develop Kuala Lumpur City Centre (KLCC) to Bukit Bintang area as a premier shopping zone in Malaysia. This project has developed pedestrian walkways and public transportation such as rail, bus service to facilitate the tourists. The Ministry of Tourism will develop the project to create estimated 14,500 new jobs.

EPP 3: Establishing three new premium outlets in Malaysia: This project will support Malaysia's tourism aspiration as a top shopping destination in Asia. This project will establish the premium outlets in three locations; Iskandar Malaysia, Sepang and Penang.

\subsubsection{Theme 2: Nature Adventure}

EPP 4: Establishing Malaysia as a global biodiversity hub: The main objective of this project is attracting international attention to Malaysia's excellent biodiversity, support responsible tourism and promote sustainable management of country's natural areas. This project will comprise that showcase the biodiversity richness of rainforests, freshwater habitats and marine environments and local flora and fauna. This project will carry on three main initiatives. These are developing Malaysia as world's top-class ecotourism destinations, provide excellence service, product package and sustainable use of resources and empower the rural communities. The Ministry of Natural Resources and Environment (NRE) and the Ministry of Tourism will work together to implement the project. This EPP will impact RM1.5 billion in GNI and about 2,900 jobs created.

\subsubsection{Theme 3: Family Fun}

EPP 5: Developing an eco-nature integrated resort in Sabah: Malaysia will develop an eco-nature integrated resort in Sabah under this project. This project will ensure green development such as energy-efficient buildings; use renewable energy, recycling and low energy consume transportations. It will displaying Sabah's rich biodiversity, mangrove forest, ecotourism, river and rainforest safari and nature lodges. The Ministry of Tourism will implement this project collaboration with Sabah State Government. This project will impact in GNI expected to be RM 707 million with about 8,000 jobs created by 2020 .

EPP 6: Creating a Straits Riviera: Malaysia will develop five purpose-built world-class cruise terminals in Penang, Sepang, Malacca, Tanjung Pelepas and Kota Kinabalu to attract the cruise passengers as well as international travelers. To ensure the success of Straits Riviera, the Ministry of Tourism and the Ministry of Transport have developed Straits Riviera Council. This council has formulated National Passenger Sea Ports and Cruise Tourism Implementation Blueprint. This project will impact in GNI expected to be RM 1.8 billion with about 9,700 jobs created by 2020 .

\subsubsection{Theme 4: Events, Entertainment, Spa and Sports}

EPP 7: Targeting more international events: Malaysia will develop three or four famous international events in country to attract the event tourists. This project will establish a dedicated events body for Malaysia to identify new international events as well as develop a cluster of events and evaluate the impact of hosted events. This project will impact in GNI expected to be RM 427 million with about 8,000 jobs created by 2020 .

EPP 8: Establishing dedicated entertainment zones: This project has been identified five cities of Malaysia as potential locations for dedicated entertainment zones. These are Greater Kuala Lumpur/Klang Valley, Genting Highlands, Penang, Langkawi and Kota Kinabalu. The expected impact of this project will be RM0.7 billion in GNI and approximately 5,614 jobs by 2020 .

EPP 9a: Developing local expertise and better regulating the spa industry: This project will develop three centers of excellence as training centers to produce skill local therapists in the spa industry. The three potential locations for training centers are greater Kuala Lumpur/ Klang Velley, Johor and Sabah. The Ministry of Tourism, the Ministry of Health and the Ministry of Housing and Local Government have established the Spa and Wellness National Council to provide accreditation and rating of spa and wellness outlets. The expected impact of this project will be RM0.4 billion in GNI and approximately 3,500 jobs by 2020 .

EPP 9b: Expanding sports tourism offering in Malaysia beyond hosting events: Malaysia has improved sports tourism by developing sports offering, especially golf tourism. Malaysia can gain approximately RM0.3 billion in GNI and create 2,100 jobs by 2020 under this project.

\subsubsection{Theme 5: Business Tourism}

EPP 10: Establishing Malaysia as a leading business tourism destination: This project will increase the business tourism from five percent to eight percent by 2020. In this period business tourists' arrival will be reached in 2.9 million. The expected impact of this project by 2020 will be RM3.9 billion in GNI and 16,700 additional jobs. 
EPP 11: Enhancing connectivity to priority medium-haul markets: Australia, India, China, Japan, Taiwan and South Korea will contribute over 90 percent of tourist arrivals from medium-haul countries by 2020. Malaysia will increase air flights in ten key cities of these six countries namely; Beijing, Delhi, Melbourne, Mumbai, Osaka, Seoul, Shanghai, Sydney, Taipei and Tokyo.

EPP 12: Improving rates, mix and quality of hotels: This project will introduce Investment Tax Allowance (ITA) to upgrade and encourage the four and five star hotels with foreign ownership. The ministry of Tourism will implement the project collaboration with MIDA. The impact expected from this project with a GNI contribution of RM5.5 billion and 64,000 additional jobs.

ETP has identified some reasons for low yield per tourist in Malaysia. The reasons are;

Lower average length of stay: The foreign tourists are staying short period in Malaysia rather than other tourism developing countries. This situation creates low yield earning from this sector.

Lower spend per day: The tourists are spending lower per day in Malaysia verses other inbound tourism markets. This is one of the main reasons for lower yielding for country's tourism industry.

Dependence on arrivals from short-haul markets: Most of foreign tourists in Malaysia come from short-haul markets. These tourists are engaging lower spend and stay rather than other neighboring countries.

ETP also select four important matters for the future development of tourism industry in Malaysia. These are;

Consumer behavior: Consumers are preparing to spend above or below for selecting goods according to their income level. For example, some tourists are choosing budget airlines to reduce cost, but staying in five-star facilities accommodations for comfortable experiences.

Attract global elites: The wealthy tourists are looking good products and service qualities in tourism sector according to their expectations. This situation is creating global elite class. Malaysian tourism industry has given more emphasized to attract these tourists for the generation of more income.

Tourism for leisure period: Now-a-days urban people are feeling stress with their workload around the world. They are interested to spend their leisure in short term holiday tourism experiences. Tourism developing countries have offered several packages to attract them.

Rise of new market leaders: Brazil, Russia, India, China and Middle East countries are recognizing as lower presented in tourism market in terms of tourists' departure and expenditures. But these countries get more importance in the world now for increasing population and economic development. The people of these countries can afford to travel for their economic enhancement. Malaysia can give special attention to these countries for tourism development.

The main advantages of this plan are giving emphasize on shopping activities; expand event, sports and business tourism and accommodation development. The plan also highlights to develop Malaysia as biodiversity hub to attract more tourists from abroad. Furthermore, the plan not formulates special guidelines for human resource development, research and education in tourism as well as foreign investment opportunities.

\subsection{National Tourism Policy (NTP)}

The Malaysian National Tourism Policy (NTP) was formulated in 1992 by the Ministry of Culture, Arts and Tourism to develop the tourism industry. This policy incorporated necessary guidelines and management practices for tourism destination development. The policy emphasized on community-based tourism, cooperation and coordination in tourism development, indentified potential tourism assets and diversification of new products mix. Ecotourism has been identified as one of the sustainable tourism form in this plan. NTP has emphasized on sustainable ecotourism development in natural areas such as highlands, coastal areas, marine parks, islands, national and state parks, geological sites, wetlands and RAMSAR sites, turtle landing sites and firefly habitats. Malaysia is a mega-diverse country in the world that gives emphasize on the preservation of environmental, social and cultural heritage of the country. Malaysian government has taken various actions to protect the natural environment and resources for tourism development. The government has formulated several policies and acts for ensuring sustainable tourism. Among them Environmental Quality Order, 1987; The Protection of Wildlife Act,1972; National Parks Act, 1980; The Fisheries Act, 1985; The National Forestry Act, 1984 and Marine Parks Malaysia Order of 1994 are mentionable. These policies and acts have played vital role for sustainable tourism development in the country (Siti-Nabiha, 2010).

The policy gives importance on local community participation in tourism activities and development. The policy categories and highlight new tourism destinations in the country wide for the entrepreneurs and tourists. But the policy not identified the community empowerment systems for tourism planning and management. Moreover, 
the plan not highlights the benefit sharing ways between local people in tourism areas.

\subsection{National Physical Plan (NPP)}

The tourism development zones have been identified and emphasized in National Physical Plan (NPP)-2. NPP has given emphasize on balanced tourism development strategy for both domestic and international markets. This strategy has focused tourists' satisfaction, ensure high quality facilities and infrastructure development and preserve and maintain tourism resources. The plan emphasized preserved and managed forests, hills, wetlands and other natural resources, the heritage sites and cultural traditions in a sustainable manner. The plan prioritized several sustainable tourism approaches such as urban tourism, coastal tourism, rural tourism, ecotourism, and cultural tourism, international shopping, tangible and intangible heritage zones and assets. Malaysian government has established and promoted sustainable tourism development as national concern for optimal use of environmental resources, preserving natural heritage and biodiversity and maintaining ecology. NPP has identified six towns namely Jerantut, Gua Musang, Gerik, Kuala Lipis, Kuala Berang and Segamat Bekok as ecotourism gateway. Ecotourism ensure environmental well being for the local community. It has minimum negative environmental impact (Malaysia, 2010a).

The plan emphasizes in different tourism segmentations development in the country. The plan also gives special attention for developing domestic tourism market in the country. The main lack of this plan is not priorities region based tourism development for different tourism segmentations.

\subsection{Local Agenda 21}

Malaysia is one of the implementer countries of Agenda 21. For this agreement, Malaysia is obliged to the idea of sustainable development. Four local authorities have implemented Local Agenda 21 (LA 21) in 2000. The authorities were Petaling Jaya City Council, Miri City Council, Kuantan Municipal Council and Kerian District Council (Awang Kepli 2006). LA 21 committees develop action plans and consciousness regarding sustainable development issues. Several members from civil society, business community and local authority are included in the committees. A total of 47 local authorities implemented LA 21 by the year 2005. Besides all local authorities in Malaysia has implemented LA 21 during the period of 9th Malaysia Plan (Malaysia, 2006). The Agenda 21 can be summarized into three components for sustainable tourism development (Tourism and Local Agenda 21, UNEP 2003). The components are,

1) To develop proper policies for stakeholder participation both in the direction and working together with community for tourism development.

2) To identify effective strategy of sustainable tourism for sustainable development that gives emphasize on stakeholders' views and other related managerial functions in the tourism destination.

3) To implement the meaningful actions that ensures economic, social and environmental sustainability of the tourism destination.

The policy gives proper guidelines and strategies for stakeholders' participation in sustainable tourism development. But the policy not includes all local authorities for sustainable tourism development. Furthermore, the policy not gives high concern for entrepreneurship development for stakeholders' participation in sustainable tourism development.

\section{Conclusion}

Tourism is the largest service sector of Malaysia in terms of foreign exchange earnings. Malaysia has targeted to capture a place within 10 countries in the world in terms of international tourist arrivals. To achieve this position, Malaysia gives emphasize on attracting non-Muslim tourists arrival in the country as well as Muslim visitors. The foreign tourist arrival and revenue earnings are increasing year by year. To meet the accommodation of tourists, investors are building new accommodation places. The earning from tourism revenue has increased every year. The Ninth and Tenth Malaysia plan has given high priority in tourism development. Malaysian government gives emphasize on sustainable tourism development in the country. The government adopts and implements various laws and regulations to ensure sustainable tourism development. Home stay and other environment friendly tourism activities are encouraged in this regard. Government has implemented necessary policies and regulations for sustainable tourism development. Government also emphasizes to tourism development in recreational forest areas, water bodies, coastal areas and other suitable places in all over the country. Despite these achievements, several issues needed to be addressed, including the need of developing ecotourism, nature tourism, cultural tourism and other potential tourism products for attracting the tourists. Community benefit sharing opportunities, attract foreign investment and region based tourism development are necessary to enhance tourism sector in Malaysia. Government can include all relevant authorities for tourism 
development in this regard. Finally, take initiatives for sufficient human resource and entrepreneurship development, give emphasize on education and research activities can be developed tourism as boosting economic sector for Malaysia.

\section{Acknowledgements}

Financial assistance provided by the Arus Perdana (AP) Research Grant (Ref. No. UKM-AP-PLW-04- 2010) and High Centre of Excellence (HiCoE) Research Grant (Ref. No. XX-05-2012) Institute for Environment and Development, University Kebangsaan Malaysia headed by Prof Chamhuri Siwar is gratefully acknowledged.

\section{References}

Ahn, B., Lee, B., \& Shafer, C. S. (2002). Operational sustainability in regional tourism planning: An application of the limits of acceptable change framework. Tourism Management, 23, 1-15. http://dx.doi.org/10.1016/S0261-5177(01)00059-0

Awang Kipli, D. S. N. (2006). Local Agenda 21 Initiative in Waste Minimization for Miri City. Forth Sabah-Sarawak Environmental Convention, 2006, Malaysia.

Bhuiyan, M. A. H., Siwar, C., Ismail, S. M., \& Islam, R. (2011). Potentials of Islamic Tourism: A case Study of Malaysia on East Coast Economic Region. Australian Journal of Basic and Applied Sciences, 5(6), 1333-1340.

Fateh, H., Rahim, K. A., Ramchandran, S., \& Chin, L. (2009). Dynamic Model for International Tourism Demand for Malaysia: Panel Data Evidence. International Research Journal of Finance and Economics, 33, 207-217.

Glasson, J., Godfrey, K., \& Goodey, B. (1995). Towards visitor impact management. Visitor impacts, carrying capacity and management responses in Europe's historic towns and cities. England: Avebury.

Hall, C. M. (1995). Introduction to tourism in Australia: Impacts, planning and development. London: Longman.

Liu, A., \& Wall, G. (2006). Planning tourism employment: a developing country perspective. Tourism Management, 27, 159-170. http://dx.doi.org/10.1016/j.tourman.2004.08.004

Malaysia. (2006a). Economic Instruments for Environmental Management in Malaysia. Economic Planning Unit, Prime Minister's Department, Putrajaya, Malaysia.

Malaysia. (2006b). Ninth Malaysia Plan 2006-2010. Economic Planning Unit, Economic Planning Unit, Prime Minister's Department, Malaysia.

Malaysia. (2007). Planning and Research Division. Ministry of Tourism. Kuala Lumpur, Malaysia.

Malaysia. (2010a). Economic Transformation Programme: A Roadmap for Malaysia. Performance Management and Delivery Unit (PEMANDU), Prime Minister's Department, Putrajaya, Malaysia.

Malaysia. (2010b). National Physical Plan-2. Federal Department of Town and Country Planning, Ministry of Housing and Local Government, 50646 Kuala Lumpur, Malaysia.

Malaysia. (2011). Tenth Malaysia Plan 2011-2015. Economic Planning Unit, Economic Planning Unit, Prime Minister's Department, Malaysia.

Malaysia. (2012). Planning and Research Division. Ministry of Tourism. Kuala Lumpur, Malaysia.

Schumacher, H. J. (2007, June 15). Let's Talk Europe: Ecotourism. Business World. p. S1/6.

Siti-Nabiha. (2010). Towards a Sustainable Tourism Management in Malaysia. Retrieved September 18, 2010, from Website "Tourism in Malaysia"

Taleghani, M. (2010). Tourism as an Economic Development Tool. Journal of American Science, 6(11), 412-416.

United Nations Environment Programme (UNEP). (2003). Tourism and Local Agenda 21. The Role of Local Authorities in Sustainable Tourism. UNEP, France.

World Travel and Tourism Council (WTTC). (2006). Malaysia: Travel and Tourism Climbing to New Heights. World Travel and Tourism Council, London.

\section{Copyrights}

Copyright for this article is retained by the author(s), with first publication rights granted to the journal.

This is an open-access article distributed under the terms and conditions of the Creative Commons Attribution license (http://creativecommons.org/licenses/by/3.0/). 